Transekonomika - Akuntansi Bisnis dan Keuangan Vol.1 No.5 September 2021

\title{
Strategi Koperasi Di Indonesia Dalam Menghadapi Era Industri 4.0
}

\author{
${ }^{1}$ Silvi Fauziyah, ${ }^{2}$ Arjuna Rizaldi \\ ${ }^{1-2}$ Universitas Komputer Indonesia
}

Article history

Received: 02-Mei-2021

Revised: 12-Juni-2021

Accepted: 28-Juli-2021

*Corresponding Author:

Silvi Fauziyah,

Arjuna Rizaldi

Universitas Komputer

Indonesia

Email:

Silvifauziyah4@gmail.com

\begin{abstract}
Abstrak: Saat ini di Indonesia era industri 4.0 menjadi era perubahan diberbagai sistem yang dilakukan secara online. Terutama pada bidang ekonomi, dan teknologi. Hal ini ditandai dengan munculnya berbagai macam sistem pembayaran yang instant dan mudah seperti melalui ATM, Mobile banking, e-money dan masih banyak lagi. Di sebuah koperasi saat ini juga menerapkan sistem online seperti untuk melakukan pembayaran transaksi. Tujuan metode penelitian ini adalah untuk mengetahui strategi koperasi di Indonesia dalam menghadapi era industri 4.0. Metode penelitian yang digunakan yaitu menggunakan metode kualitatif dimana teknik pengumpulan data tersebut di lakukan dengan cara studi literatur yaitu dengan mengumpulkan data-data yang berhubungan dengan topik penelitian. Studi literatur bisa diperoleh dari berbagai sumber seperti jurnal ilmiah, buku, dan internet. Berdasarkan hasil penelitian beberapa strategi yang dapat dilakukan koperasi dalam menghadapi era digital adalah dengan 1) Peningkatan sumber daya manusia yang harus dapat menguasai teknologi digital dan teknologi informasi melalui pelatihan atau bimbingan; 2) Pentingnya meningkatkan modal koperasi untuk terus berkembang seiring dengan kemajuan teknologi yang semakin pesat; 3) Melakukan pembenahan keterampilan manajerial untuk dapat mengelola koperasi dengan baik; 4) Melakukan perubahan strategi pemasaran dengan cara memanfaatkan teknologi digital.
\end{abstract}

Kata Kunci : Perkembangan Ekonomi, Koperasi, Era Industri 4.0, Tantangan, Strategi

\section{PENDAHULUAN}

Pada tahun 2030 Indonesia akan menerapkan konsep revolusi industri 4.0. Dalam era industri 4.0 tentunya akan berdampak terhadap kehidupan diantaranya pada sektor industri, pendidikan, pemerintahan dan koperasi. Koperasi di harapkan harus mampu beradaptasi dan bertransformasi dalam menghadapi era industri 4.0. Insan koperasi di harapkan mampu membangun karakter kreatif dan inovatif, dan bisa mengembangkan koperasi dengan strategi bisnisnya sesuai dengan era industri 4.0. Perubahan yang terjadi pada era industri ditandai dengan pesatnya teknologi digital. Pemanfaatan teknologi digital sudah menjadi bagian hidup kaum milenial, ditandai dengan ketergantungan terhadap teknologi dan internet dalam aktivitas sehari-hari. Akan tetapi, dalam pertumbuhan nya koperasi masih belum mengimbangikualitasnya dengan baik, sehingga mengakibatkan banyak koperasi yang tidak berkembang. Dari permasalahan tersebut perlu untuk melakukan penelitian mengenai bagaimana strategi yang dikembangkan koperasi dalam menghadapi era industri 4.0. Tujuan dari penelitian ini adalah untuk mengetahui strategi yang diambil oleh sebuah koperasi untuk meningkatkan perkembangan nya di era industri 4.0. 


\section{TINJAUAN PUSTAKA}

\section{Koperasi}

Koperasi adalah badan usaha yang beranggotakan orang-orang atau badan hukum koperasi dengan berlandaskan kegiatannya berdasarkan prinsip koperasi sekaligus sebagai gerakan ekonomi rakyat yang berdasarkan atas asas kekeluargaan.Menurut Hendrojogi (2007:22) mendefinisikan koperasi sebagai berikut: "Koperasi ialah perkumpulan dari orang-orang yang atas dasar persamaan derajat sebagai manusia, dengan tidak memandang haluan agama dan politik secara sukarela masuk, untuk sekedar memenuhi kebutuhan bersama yang bersifat kebendaan atas tanggungan bersama." (Mahadiet al., 2020).

Koperasi merupakan badan usaha yang bertujuan mensejahterakan anggota pada khususnya dan masyarakat pada umunya. Dalam praktik usahanya koperasi tidak hanya mencari keuntungan yang sebesar-besarnya, akan tetapi lebih mengutamakan pelayanan terhadap anggota atau lebih mengutamakan kesejahteraan anggotanya.(Sri, 2010).

\section{Era Industri 4.0}

Era revolusi industri 4.0 adalah sebuah istilah yang diciptakan pada tahun 2011 oleh jerman ditandai dengan perubahan teknologidan mengarah kepada revolusi digital. Teknologi digital banyak digunakan oleh industri untuk proses produksi yang diyakini mampu meningkatkan kualitas dan kuantitas produk, teknologi ini mulai diterapkan dari $3 \mathrm{D}$ printing sampai dengan pengoperasian menggunakan robotik. Perubahan yang terjadi di era revolusi industri berdampak terhadap industri, ekonomi, dan pemerintahan.(Venti,2018).

Revolusi Industri berdampak terhadap kehidupan manusia terutama terhadap penggunaan teknologi digital. Dimana semua proses dilakukan dengan teknologi internet dan berbasis pada proses transaksi dan transfortasi secara online. Aplikasi yang digunakan berbasis teknologi akan mempermudah proses, baik proses produksi maupun proses pemasaran.(Hamdan, 2018).

\section{METODE PENELITIAN}

Pada metode penelitian inimenggunakan metode kualitatif dimana teknik pengumpulan datadilakukan dengan cara studi literatur yaitu dengan mengumpulkan data-data yang berhubungan dengan topik penelitian. Data-data tersebut dapat diambil dari jurnal ilmiah, buku , artikel penelitian, situs online di internet dan sebagainya. Tujuan penelitian ini yaitu agar mampu memahami strategi yang digunakankoperasi di Indonesia dalam menghadapi era industri 4.0.

Studi literatur adalah pendekatan penelitian yang dapatdilakukan dengan cara mencari referensi atas landasan teori yang relevan dengan kasus atau permasalahan yang dihadapi. Dengan menggunakan metode studi literatur peneliti dapat memanfaatkan semua informasi yang berkaitan dengan permasalah dan menganalisis hasil yang diperoleh dari penelitiannya.

\section{HASIL PENELITIAN DAN PEMBAHASAN}

Era revolusi industri saat ini sedang mengalami perubahan besar. Diantara perubahan yang sedang dihadapi saat ini ialah perubahan teknologi yang menggabungkan dunia fisik, dan digital dengan cara yang fundamental. Transformasi ini akan berdampak positif , dimana adanya peran dunia usaha dan organisasi sosial di nilai strategis dalam memperkuat kemandirian ekonomi bangsa. Dengan meningkatnya kemandirian ekonomi dapat memberikan dampak terhadap kewirausahaan sehingga dapat mencapai tingkat kesejahteraan masyarakat secara merata. (Hamdan, 2018).

Untuk mendapatkan daya saing infrastruktur negara-negara maju dapat menggunakan cara 
melalui industri 4.0 . Sedangkan untuk negara-negara berkembang, industri 4.0 digunakan untuk membantu menyederhanakan rantai suplai produksi guna menyiasati biaya tenaga kerja yang kian meningkat. Penguasaan teknologi menjadi kunci penentu daya saing di era industri 4.0.(Venti, 2018).

Perkembangan era revolusi industri 4.0 tidak hanya diperuntukkan iklim usaha makro tetapi iklim usaha mikro juga ikut terlibat sebagai penggerak perekonomian daerah. Dimana setiap kegiatan industri/manufaktur harus melibatkan sistem digital. Saat ini, UMKM menjadi perkembangan ekonomi yang cepat di Indonesia berkisaran 90-95\% yang ditunjukan ketika krisis ekonomi berlangsung tetapi masih memiliki pasar yang kuat. Akan tetapi UMKM masih memiliki kelemahan diantaranya kurangnya permodalan, keterampilan manajerial, keterampilan beroperasi dalam mengorganisir, serta pemasaran. UMKM memiliki kesulitan dalam mengaplikasikan teknologi industri 4,0 yang disebabkan tidak memiliki tenaga, serta diluar jangkauan UMKM dalam hal produk dan produksi.(Rianita dan Deri, 2019; Endra et al., 2018).

Pada era industri 4.0 para pelaku UMKM diharapkan mampu menguasai teknologi dan informasi agar dapat terhindar dari ketertinggalan teknologi dan agar mampu bersaing pada era revolusi industri 4.0.(Dendy et al., 2018).

Dalam pemanfaatan internet untuk berbagai aktivitas yang digunakan dalam hal kegiatan bisnis yang dilakukan secara online disebut dengan E-commerce. Peran E-commerce dalam kegiatan bisnis sangat memudahkan pelaku bisnis agar dapat berkomunikasi dengan pembelinya. Dalam mempromosikan produknya para pelaku usaha kecil dan menengah (UKM) juga memanfaatkan ecommerce dengan baik. Sarana E-commerce yang sering digunakan perusahaan UKM adalah e-mail dan website.(Shinta, 2020).

Masyarakat Indonesia umumnya sangat kental dengan kekeluargaan dan kegotongroyongan , inilah yang menjadi azas koperasi di Indonesia. Bangsa Indonesia telah lama mengenal kekeluargaan dan kegotongroyongan sejak lama oleh nenek moyang bangsa Indonesia. Kebiasaan ini merupakan input pasal 33 ayat 1 UUD 1945 yang dijadikan dasar/pedoman pelaksaan koperasi. Seiring dengan berjalannya waktu, perkembangan koperasi masih menghadapi masalah-masalah baik dalam bidang kelembagaan maupun dalam bidang usaha koperasi itu sendiri. Masalah koperasi dapat berupa intern dan ekstren. Dimana masalah intern mencakup masalah keanggotaan, kepengurusan, pengawas, manajer, dan karyawan koperasi. Sedangkan masalah ekstren mencakup hubungan koperasi dengan bank, usaha-usaha lain, dan juga dengan instansi pemerintah.

Berikut masalah koperasi secara umum dan cara mengatasinya :

1. Koperasi jarang peminat

Maksud dari Koperasi jarang peminatnya ialah Pandangan masyarakat tentang koperasi saat ini masih terlalu minim untuk itu diharapkan perlu adanya sosialisasi terhadap masyarakat untuk dapat mengetahui bahwa sebenarnya koperasi merupakan ekonomi rakyat yang dapat menyejahterakan anggotanya.

2. Kualitas sumber daya yang tebatas

Kurang nya sumber daya manusia yang dapat menyebabkan koperasi sulit berkembang, solusinya yaitu memberikan pengarahan kepada koperasi kepada generasi muda melalui pendidikan agar mereka dapat berpartisipasi dalam koperasi.

3. Banyaknya pesaing dengan usaha yang sejenis

Hal yang dapat dilakukan dalam menanggapi pesaing ialah kita harus mempunyai trik atau langkah khusus, misalnya dalam memberikan pembayaran sistem kredit yang dapat dilakukan dalam waktu mingguan ataupun bulanan sesuai perjanjian.

4. Keterbatasan Modal

Perlu adanya perhatian yang besar dari pemerintah kepada koperasi untuk dapat menangani masalah permodalan. Selain itu, peran masyarakat juga sangat penting untuk permodalan koperasi sehingga dapat bertahan dan berkembang.

5. Partisipasi anggota

Dalam sebuah koperasi anggota berperan dalam memajukan koperasi dan ikut serta mendukung 
program-program yang dijalankan pada sebuah koperasi tersebut., dan pengambilan keputusan harus atas dasar musyawarah bersama anggota koperasi.

6. Perhatian pemerintah

Peran pemerintah dalam mengawasi koperasi sangat dibutuhkan agar koperasi dapat berkembang dengan baik. Dan pemerintah juga dapat membuat kebijakan untuk dapat membantu kemajuan koperasi.

7. Manajemen koperasi

Perlu adanya manajemen koperasi agar setiap perencanaan, pengorganisasian, pengarahan, dan pengawasan dapat berjalan dengan baik.(Camelia dan hasyim, 2018).

Koperasi dapat berjalan dengan baik dan berkembang dengan memperhatikan prinsip-prinsip sebagai berikut, ICA (2011) Menetapkan prinsip dan nilai yang harus dijalankan oleh sebuah koperasi, ada tujuh prinsip : 1) Keanggotaan sukarela dan terbuka; 2) kontrol anggota demokratis; 3) partisipasi ekonomi anggota; 4) otonomi dan kemerdekaan; 5) pendidikan, pelatihan dan informasi; 6) kerjasama antar koperasi; 7) kepedulian terhadap masyarakat koperasi merupakan lembaga yang harus dikelola sebagaimana layaknya lembaga bisnis.(Dendy et al., 2018).

Sektor usaha dipulau Bali ialah sektor pariwisata, hal ini tentunya bisa berdampak pada sektor perekonomian seperti koperasi. Dari data-data yang ada sejak tahun 2019 jumlah koperasi di Bali sebesar 5.024 koperasi. Namunsaat ini koperasi mengalami berbagai macam permasalahan yang dihadapi. Diantara permasalah tersebut yaitu kualitas sumber daya manusia yang masih rendah sebagai pengelola koperasi, pertumbuhan koperasi yang masih rendah, keterbatasan dalam hal memasarkan produk, dan kurangnya akses modal yang ada pada koperasi.(Mahadi et al., 2020).

Berdasarkan hasil dan pembahasan di atas maka strategi yang dapat digunakan koperasi dalam menghadapi era industri 4.0 adalah 1) Peningkatan sumber daya manusia yang harus dapat menguasai teknologi digital dan teknologi informasi melalui pelatihan atau bimbingan; 2) Pentingnya meningkatkan modal koperasi untuk terus berkembang seiring dengan kemajuan teknologi yang semakin pesat; 3) Melakukan pembenahan keterampilan manajerial untuk dapat mengelola koperasi dengan baik; 4) Melakukan perubahan strategi pemasaran dengan cara memanfaatkan teknologi digital.

\section{KESIMPULAN}

Di era industri 4.0 pemanfaatan teknologi dan informasi sudah semakin pesat. Hal itu tidak terlepas dari perekonomian terutama pada sektor koperasi, Dimana setiap kegiatan yang dilakukan sudah mengalami perubahan yang semula konvensional dengan adanya era industri menjadi digital. Permasalahan yang dihadapi koperasi di era industri 4.0 adalah minimnya para anggota koperasi dalam menggunakan teknologi digital, kurangnya modal koperasi, kurangnya penguasaan manajerial dan pemasaran.strategi yang dapat digunakan koperasi dalam menghadapi era industri 4.0 adalah 1) Peningkatan sumber daya manusia yang harus dapat menguasai teknologi digital dan teknologi informasi melalui pelatihan atau bimbingan; 2) Pentingnya meningkatkan modal koperasi untuk terus berkembang seiring dengan kemajuan teknologi yang semakin pesat; 3) Melakukan pembenahan keterampilan manajerial untuk dapat mengelola koperasi dengan baik; 4) Melakukan perubahan strategi pemasaran dengan cara memanfaatkan teknologi digital.

Berdasarkan hasil penelitian dapat di ambil beberapa rekomendasi diantaranya perlunya peran pemerintah untuk meningkatkan perkembangan koperasi agar dapat bersaing di era industri 4.0. 


\section{DAFTAR PUSTAKA}

Akbar, D.S., \& Apip, M., \& Usmar, D. 2018. Strategi Pengembangan UMKM Dalam Menghadapi Era Industri 4.0 Dalam Perspektif Akuntansi, Jurnal ISEI. 43-48.

Arifianto, E.Y., \& Sulistyarini, D.H., \& Himawan, R., \& Cahyawati, A. 2018. Perancangan Sistem lembaga keuangan Mikro Guna Mendukung Perekonomian Mayarakat Desa Di Era Industri 4.0, SENIAS. 7-11.

Avriyanti, S. 2020. Peran E-Commerce untuk meningkatkan keunggulan kompetitif Di Era Industri 4.0 ( Studi pada UKM yang terdaftar pada dinas koperasi usaha kecil dan menengah kabupaten Tabalong), Jurnal PuBis. 82-99.

Dwipradnyana, I.M.M., \& Pratiwi, I.G.A.M.A.M.A., \& Diatmika, I.G.N.D. 2020. Strategi Pengembangan Koperasi Di Era Digital Pada Koperasi Yang Ada Di Provinsi Bali, Majalah Ilmiah Untab. 112-116.

Hamdan. 2018. Pengaruh Revolusi Industri Pada Kewirausahaan Demi Kemandirian Ekonomi, JURNAL NUSAMBA. 1-8.

Sari, R.P., \& Santoso, D.T.2019. Pengembangan Model Kesiapan UMKM di Era Revolusi Industri 4.0, Jurnal Media Teknik \& Sistem Industri (JMTSI). 37-42.

Satya, V.E.2018. Strategi Indonesia Menghadapi Industri 4.0, INFO Singkat. 19-24.

Sitepu, C.F., \& Hasyim.2018. Perkembangan Ekonomi Koperasi Di Indonesia, NIAGAWAN. 59-68.

Zulhartati Sri.2010. Peran Koperasi Dalam Perekonomian Indonesia, Guru Membangun. 1-7.

Sujarwo., \& Listiawati, R.2018. Pengembangan Bisnis Koperasi Kampus (Era Milenial \& Revolusi Industri Ke-4.0), Mitra Akademia. 1-6. 